\title{
REVIEW
}

\section{Relation between exposure to asbestos and smoking jointly and the risk of lung cancer}

\author{
P N Lee
}

\begin{abstract}
Objectives-To review evidence about the joint relation of exposure to asbestos and smoking on the risk of lung cancer to answer three questions: (1) does asbestos increase risk in non-smokers; (2) are the data consistent with an additive model; and (3) are the data consistent with a multiplicative model?

Methods-Analysis of 23 studies reporting epidemiological evidence on the joint relation. Comparison of risk of lung cancer in subjects unexposed to asbestos or smoking, exposed to asbestos only, to smoking only, or to both. Estimation of the relative risk associated with asbestos exposure in non-smokers and of statistics testing for additivity and multiplicativity of risk.
\end{abstract}

Results-Eight of the 23 studies provided insufficient data on the risk of lung cancer in non-smokers to test for possible effects of asbestos. Asbestos exposure was associated with a significantly $(p<0.05)$ increased risk in non-smokers in six of the remaining studies and with a moderately increased, but not significant, increase in a further six. In two of the three studies that found no increase, asbestos exposure was insufficient to increase risks in smokers. In 30 of 31 data sets analysed, risk in the combined exposure group was greater than predicted by the additive model. There was no overall departure from the multiplicative model, the proportional increase in risk of lung cancer with exposure to asbestos being estimated as 0.90 (95\% confidence interval $(95 \%$ CI 0.67 to 1.20$)$ times higher in smokers than non-smokers. For two studies significant $(p<0.05)$ departures from a multiplicative relation were found in some, but not all, analyses. Reasons are presented why these may not indicate true model discrepancies.

Conclusions-Asbestos exposure multiplies risk of lung cancer by a similar factor in non-smokers and smokers. The extent to which it multiplies risk varies between studies, no doubt depending on the type of asbestos involved, and the nature, extent, and duration of exposure.

(Occup Environ Med 2001;58:145-153)

P N Lee

PeterLee@pnlee.demon.co.uk

Accepted 19 October 2000
Keywords: lung neoplasms; smoking; asbestos
Lung cancer incidence is clearly increased by both smoking and exposure to asbestos, but the joint relation is not well defined. Suppose that risks are 1 unit for a non-smoker unexposed to asbestos, A units for a non-smoker exposed to asbestos, and $\mathrm{S}$ units for an unexposed smoker. Various possible models predict risk in a smokers exposed to asbestos. In the additive model the excess risks add to give a predicted risk of $1+(\mathrm{A}-1)+(\mathrm{S}-1)=\mathrm{A}+\mathrm{S}-1$ units. In the multiplicative model the two proportional increases multiply to give AS units. In the intermediate model the risk lies between $\mathrm{A}+\mathrm{S}-1$ and AS units; in the supermultiplicative model it exceeds AS. Note that to test the models only requires data on the relative, not absolute, risks and also that the models, if correct, should apply equally to risk differences relating to high versus low exposure as to those relating to exposed versus unexposed.

We examine studies investigating the relation of lung cancer to both agents to answer three questions:

(1) Does asbestos increase lung cancer risk in non-smokers?

(2) Do the data fit an additive model, or is the absolute risk increase from asbestos greater for smokers than non-smokers? and

(3) Do the data fit a multiplicative model, or does the relative risk increase from asbestos vary by smoking?

Other published reviews ${ }^{1-7}$ are not comprehensive and do not answer all these questions clearly.

\section{Methods}

Relevant papers were obtained from in house files, additional papers identified from Medline and Embase searches, and papers cited as references. Studies had to report evidence on the joint relation of smoking and asbestos to lung cancer. One study ${ }^{8}$ concerning location and histology of lung cancer, but not risk itself, was excluded.

Study details extracted included its location, timing, and design, the number of lung cancers, how they were diagnosed, and how asbestos exposure and smoking were defined. To test the various hypotheses, subjects were categorised into four groups: unexposed to asbestos or smoking ( $\left.\mathrm{A}^{-} \mathrm{S}^{-}\right)$, or exposed to asbestos only $\left(\mathrm{A}^{+} \mathrm{S}^{-}\right)$, smoking only $\left(\mathrm{A}^{-} \mathrm{S}^{+}\right)$, or both $\left(\mathrm{A}^{+} \mathrm{S}^{+}\right)$. Sometimes $\mathrm{A}^{-}$included low exposure to asbestos and $\mathrm{S}^{-}$included light smoking. 
Summary statistics allowing comparison of risk in the four groups were extracted or calculated. ${ }^{9}$ For case-control studies, these were numbers of cases and controls by group and estimates, derived from odds ratios, of risk relative to $\mathrm{A}^{-} \mathrm{S}^{-}$(or to $\mathrm{A}^{+} \mathrm{S}^{-}$if no cases in $\mathrm{A}^{-} \mathrm{S}^{-}$). For cohort and occupational studies, relative risks were derived from standardised mortality ratios (SMRs), incidence ratios (SIRs), or lung cancer rate estimates. In some cohort and occupational studies (group A) internal data were available for all four groups. In others (group B), where the whole population was considered to be exposed to asbestos $\left(\mathrm{A}^{+}\right)$and comparisons were made to an external standard, SMRs/SIRs were only available for $\mathrm{A}^{+} \mathrm{S}^{-}$ and $\mathrm{A}^{+} \mathrm{S}^{+}$. Here relative risks were calculated assuming (from 40 year follow up data for male British doctors ${ }^{10}$ ) that the relative risk for smoking in those unexposed to asbestos was 7.13, with the SMR 0.15 for $\mathrm{A}^{-} \mathrm{S}^{-}$and 1.07 for $\mathrm{A}^{-} \mathrm{S}^{+}$. Sensitivity analyses were also carried out with alternative smoking risk estimates of 3, 5, and 10 . Where expected (E) numbers of lung cancers were presented to a common reference, SMRs/SIRs were calculated from the observed (O)/expected (E) ratio. Where expected numbers provided were adjusted for smoking (ES), SMRs were calculated by multiplying O/ES by 0.15 for $\mathrm{S}^{-}$and by 1.07 for $\mathrm{S}^{+}$, again from the data from British doctors.

Where data permitted, study specific estimates were made of the relative risk from asbestos in non-smokers, and of statistics testing for additivity, $U$, and multiplicativity, $V$. $U=R_{1}-R_{2}-R_{3}+R_{4}$ and $V=R_{1} R_{4} / R_{2} R_{3}$ where $R_{1}, R_{2}$, $R_{3}$ and $R_{4}$ are the relative risks in, respectively, groups $\mathrm{A}^{-} \mathrm{S}^{-}, \mathrm{A}^{+} \mathrm{S}^{-}, \mathrm{A}^{-} \mathrm{S}^{+}$, and $\mathrm{A}^{+} \mathrm{S}^{+} .95 \%$ Confidence intervals (95\% CIs) of the asbestos risk in non-smokers and of $V$ were calculated assuming the relative risk is log normally distributed.

Multiplicativity was further tested by fitting logistic or log linear models, and by fixed effects meta-analyses ${ }^{11}$ of $V$. Percentage attributable risks (PARs) were estimated for each study based on the relative risks fitted to the multiplicative model $\left(F_{1}, F_{2}, F_{3}, F_{4}\right)$ and the population distribution of exposure. ${ }^{212}$ Thus, deaths were divided as in table 1 .

\section{Results}

STUDY CHARACTERISTICS

Tables 2-4 summarise characteristics of, respectively, nine case-control studies (including two nested within an occupational study), ${ }^{13-23}$ seven group A cohort and occupational studies, ${ }^{124-29}$ and seven group B cohort and occupational studies. ${ }^{30-36}$ Twelve studies were conducted in Europe, seven in North America, three in Asia, and one in Australia.

Table 1 Multiplicative model $\left(F_{1}, F_{2}, F_{3}, F_{4}\right)$ and the population distribution of exposure

\begin{tabular}{lllll}
\hline \multirow{5}{*}{ Group } & \multicolumn{3}{l}{ Proportion of deaths attributed to } \\
\cline { 2 - 5 } & Background & Asbestos only & Smoking only & Both factors \\
\hline $\mathrm{A}^{-} \mathrm{S}^{-}$ & 1 & - & - & - \\
$\mathrm{A}^{+} \mathrm{S}^{-}$ & $1 / \mathrm{F}_{2}$ & $\left(\mathrm{~F}_{2}-1\right) / \mathrm{F}_{2}$ & $\overline{-}$ & - \\
$\mathrm{A}^{-} \mathrm{S}^{+}$ & $\left.1 / \mathrm{F}_{3}-1\right) / \mathrm{F}_{3}$ & $\overline{-}$ \\
$\mathrm{A}^{+} \mathrm{S}^{+}$ & $1 / \mathrm{F}_{4}$ & $\left(\mathrm{~F}_{2}-\mathrm{F}_{3}+\mathrm{F}_{4}\right) / \mathrm{F}_{4}$ \\
\hline
\end{tabular}

Four studies were conducted in miners (and millers), two of chrysotile, ${ }^{1524}$ one crocidolite ${ }^{13}$ and one anthophyllite asbestos. ${ }^{28}$ Seven were conducted in asbestos products workers, two of chrysotile, ${ }^{25} 26$ two amosite, ${ }^{27}{ }^{34}$ one crocidolite and chrysotile ${ }^{1}$ and two of unstated asbestos type. $^{3033}$ One study was of workers in a nitric acid production plant, ${ }^{29}$ one of asbestos sprayers and of patients with asbestosis and silicosis, ${ }^{31}$ and three of insulation workers. ${ }^{32} 3536$ The remaining seven studies were case-control, in railway workers, ${ }^{20}$ industrial areas, ${ }^{16}$ and shipbuilding areas. ${ }^{14} 17-1921-23$

Of the 16 occupational cohort studies, four started follow up in the $1940 \mathrm{~s}$, four in the 1950s, five in the 1960s, and three in the 1970s. Follow up ranged from 9-42 years. For many studies with follow up starting early, smoking habits were obtained later, limiting numbers of lung cancers where analysis by smoking was possible. Fourteen occupational cohort studies reported results for lung cancer mortality, based on death certificates only in eight and also based on medical records in six. The other two reported cancer incidence. Of seven (nonnested) case-control studies, two involved hospital patients, three dead cases, and two both. One case-control study used general population controls. The rest used hospital controls for hospital cases and dead controls for dead cases, with varying exclusions used for controls (table 2).

Numbers of lung cancers with available data about smoking varied, from at most 50 in eight studies to about 1000 in two. Many larger studies involved few cases with severe asbestos exposure. The studies of chrysotile miners and millers in Quebec ${ }^{24}$ and of insulation workers in the United States and Canada ${ }^{36}$ involved the most severely exposed cases. Many studies had few cases, so lacking power to detect asbestos risks in non-smokers.

\section{DATA ON ASBESTOS AND SMOKING}

Tables 5-7 define exposures and present relevant data. Generally, the studies considered correspond to those described in tables 2-4 respectively. However, in four studies ${ }^{12427} 28$ table 6 shows analyses comparing risk of high and low asbestos exposure within the study and table 7 shows analyses of high exposure with an external standard.

Definitions and sources of asbestos exposure varied. In some studies in table $7^{36}$ the risk of the whole population was compared with an external standard, exposure being inferred from the occupation. In most occupational and cohort studies, subjects were categorised into high or low exposure based on work history, sometimes supplemented by dust measurements. For case-control studies evidence of exposure was usually derived from work history obtained from various sources (work records, interview of patient, interview of proxy). In the studies by Blot et $a l^{21-23}$ data were collected only on shipyard employment.

Data on smoking were obtained by proxy interview in over a third of studies. Although some studies separated results for ever and never smokers, the $S^{-}$category often included 


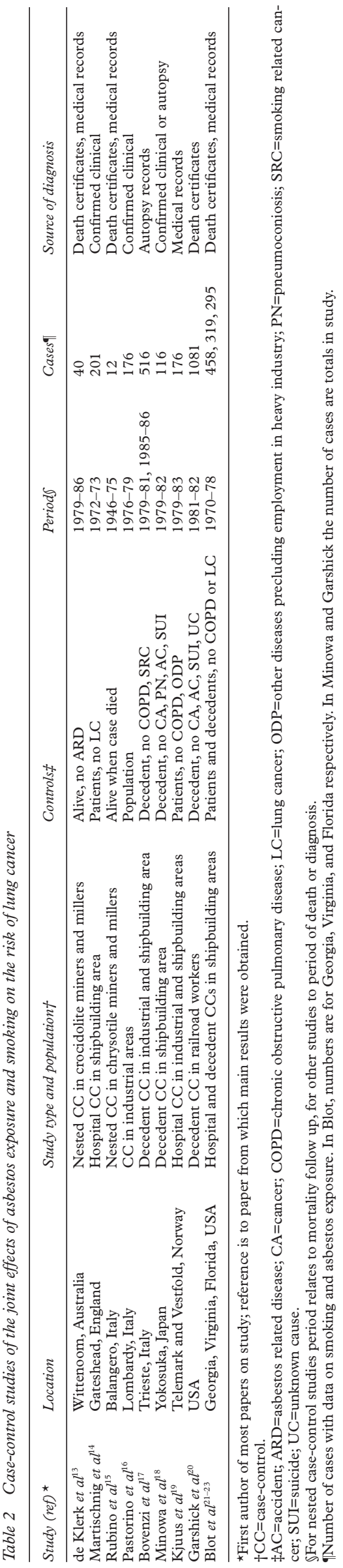

light smokers, ex-smokers, or non-cigarette smokers.

Generally, age was taken into account in design or analysis, but other environmental causes of lung cancer were not (data not shown). However, the data of Pastorino et al ${ }^{16}$ were subdivided by exposure to polycyclic aromatic hydrocarbons, Garshick et al ${ }^{20}$ considered diesel exposure, and Selikoff et $a l^{34}$ and Hammond et $a l^{36}$ sought comparability of the study and reference group by calculating expected values for United States white men who were not farmers, had at most high school education, and had been occupationally exposed to dust, fumes, vapours, gases, chemicals, or radiation.

Some risk estimates shown in tables 5-7 are based on few lung cancers. For some studies, not all the required data were estimable.

ANSWERING THE THREE QUESTIONS OF INTEREST Based on the data in tables 5-7 (or sometimes additional data available), tables $8-10$ present results of analyses investigating the three questions of interest.

The data generally showed a clearly increased risk of lung cancer with smoking (ignoring asbestos), and with asbestos (ignoring smoking).

Only three studies failed to show a significantly increased risk of lung cancer with asbestos for the whole population. The study of railway workers ${ }^{20}$ and the study of asbestos cement workers $^{30}$ showed little or no relation, whereas the study of Italian chrysotile miners and millers $^{15}$ reported a relative risk of 2.89 (95\% confidence interval $(95 \% \mathrm{CI}) 0.58$ to 14.4$)$ for high to low exposure, based on only 12 lung cancers.

DOES ASBESTOS INCREASE THE RISK OF LUNG CANCER IN NON-SMOKERS?

Rubino et $a l^{15}$ provided no useful information, as no lung cancers occurred in non-smokers and comparisons were only made within the study. Nor did Minowa et a $l^{18}$ because of inadequate reporting. The other 21 studies can be considered as four sets. The first showed a significantly increased relative risk (in at least one analysis) of $25.0,{ }^{34} 11.5,{ }^{1} 8.44,{ }^{35} 5.71,{ }^{36} 4.07,{ }^{24}$ and $3.78 .^{26}$ The second reported at least a moderate increase which was not significant (or significance could not be tested). Relative risks were $5.44,{ }^{25} 2.52,{ }^{16} 2.41,{ }^{19} 1.90,{ }^{13} 1.83,{ }^{17}$ and 1.28, 1.88, and 1.80 (three United States states). ${ }^{21-23}$ The third showed little evidence of an effect of asbestos in non-smokers. Neuberger and $\mathrm{Kundi}^{30}$ and Garshick et $a l^{20}$ have already been noted to show little evidence of an effect overall, whereas Martischnig et $a l^{14}$ had wide $95 \%$ CIs of 0.38 to 3.06 . The final set had virtually no power. ${ }^{27-29}$ 31-33

The evidence clearly indicates that, provided exposure is sufficient to increase risk in the overall population, and enough non-smokers are studied, an increased risk of lung cancer in non-smokers after exposure to asbestos can be shown. The magnitude of the increase depends on the extent and nature of exposure. 
Table 3 Cohort and occupational studies of the relation between asbestos exposure and smoking jointly and the risk of lung cancer (with internal data for all four comparison groups (group $A)$ )

\begin{tabular}{|c|c|c|c|c|c|c|}
\hline Study $(\text { ref })^{\star}$ & Location & Study population & Follow up period & End point & Casest & Source of diagnosis \\
\hline McDonald et a $l^{4}$ & Quebec, Canada & Chrysotile miners and millers & $1950-92$ & Mortality & 299 & Death certificates \\
\hline Cheng and Kong ${ }^{25}$ & Tianjin, China & Chrysotile asbestos products workers & $1972-87$ & Mortality & 21 & Not given \\
\hline Zhu and Wang ${ }^{26}$ & 8 factories, China & Chrysotile asbestos products workers & $1972-86$ & Mortality & 57 & Death certificates, medical records \\
\hline Berry et al $\ddagger^{1}$ & East London, England & Asbestos factory workers & $1960-70,1971-80$ & Mortality & 79 & Death certificates \\
\hline Acheson et $a l^{27}$ & Uxbridge, England & Amosite asbestos factory workers & $1947-79$ & Mortality & 22 & Death certificates \\
\hline Meurman et al ${ }^{28}$ & North Savo, Finland & Anthophyllite miners & 1953-91 & Incidence & 55 & Cancer registration \\
\hline Hilt et al ${ }^{29}$ & Telemark, Norway & Workers in nitric acid production plant & $1953-80$ & Mortality & 127 & Death certificates \\
\hline
\end{tabular}

${ }^{\star}$ First author of most papers on study; reference is to paper from which main results were obtained.

†Number of cases with data on smoking and asbestos exposure.

$\ddagger$ Results were presented for two separate follow up periods; internal data was only available for 1960-70.

DO THE DATA FIT AN ADDITIVE MODEL?

For an additive model, the sum of risks for $\mathrm{A}^{-} \mathrm{S}^{-}$ and $\mathrm{A}^{+} \mathrm{S}^{+}$should equal that for $\mathrm{A}^{+} S^{-}$and $\mathrm{A}^{-} \mathrm{S}^{+}$. Tables 8-10 present a statistic $(U)$ testing additivity based on the difference of the sums. Overall, there are 31 estimates of $U, 30$ indicating that the response is higher than expected for $\mathrm{A}^{+} \mathrm{S}^{+}(\mathrm{p}<0.001)$. Some studies show very clear departures from additivity, notably, ${ }^{36}$ where the increased risk from asbestos in smokers is reliably estimated at about 40 times the baseline risk. Had the increase in non-smokers been 40 times the baseline risk, about 60 lung cancer deaths would have been expected in the non-smoking workers, but only eight were found. Other studies show quite clearly non-additive results. ${ }^{19} 293134$

DO THE DATA FIT A MULTIPLICATIVE MODEL?

For a multiplicative model, the product of risks for $\mathrm{A}^{-} \mathrm{S}^{-}$and $\mathrm{A}^{+} \mathrm{S}^{+}$should equal that for $\mathrm{A}^{+} \mathrm{S}^{-}$and $\mathrm{A}^{-} \mathrm{S}^{+}$. Tables $8-10$ present a statistic $(V)$ testing multiplicativity, based on the ratio of the products. $V$ is not obviously consistently greater or less than 1.0. Restricting attention to table 9 rather than table 10 estimates of $V,{ }^{12427}{ }^{28}$ and excluding undefined or infinite estimates (all based on few cases), meta-analysis of 16 individual estimates gave an estimate of 0.90 (95\% CI 0.67 to 1.20 ), with no significant heterogeneity between estimates.

Tables 8-10 also include results of formal model fitting, showing estimated risks for asbestos exposure alone (A), smoking alone (S) and their product (AS), as well as the deviance, distributed approximately as $\chi^{2}$ on 1 degree of freedom.

Based on the deviances (or, equivalently, on the $95 \%$ CIs of $\mathrm{V}$ ), only four estimates show any indication of departure from multiplicativity.

For the data of Martischnig et $a l^{14}$ (table 8), the deviance, 3.08, was only significant at $\mathrm{p}<0.1$, so chance cannot be excluded.
Chance also cannot be excluded for the analysis of Berry et a $l^{1}$ for women for 1971-80 (table 10), where the deviance was 3.51. The analysis compares an observed relative risk of smoking of 2.26 in female with a value of 7.13 for male British doctors. Use of a lower reference eliminates the discrepancy.

For the data of McDonald et $a l,{ }^{24}$ two analyses were conducted. The first (table 9) tests if the relative increase in risk for smoking was similar in men with high and low exposure to asbestos. Although less in those with high exposure (2.73) than with low exposure (4.46) the difference was not significant. The second (table 10) tests if the relative increase in risk from smoking in men with high exposure to asbestos was similar to that for British doctors. The difference (2.73) versus (7.13) was significant. The first analysis avoids assuming that smoking habits of British doctors and Quebec miners are similar and the problem that pipe and cigar smoking were only accounted for in the study of doctors. The data from the study by McDonald et al do not clearly show true departure from the multiplicative model.

The largest deviance $(15.85, \mathrm{p}<0.001)$ occurred for the study of Selikoff et al (table 10). ${ }^{34}$ Forty five deaths occurred from lung cancer, among ever smokers of cigarettes, compared with 9.6 expected for men with the same smoking history in the American Cancer Society's million people study, and five deaths occurred as against 0.2 expected among men who had never smoked, $V$ being estimated as 0.19 (95\% CI 0.07 to 0.61$)$. This analysis was based on death certificate diagnoses to make it comparable with the reference population. However, based on the "best available evidence", there were 55 deaths from lung cancer among smokers and three among nonsmokers. ${ }^{13}{ }^{34}$ With these numbers, $V$ becomes a non-significant 0.38 (95\% CI 0.12 to 1.91 ). Although the revised analysis ignores misdiag-

Table 4 Cohort and occupational studies of the relation between asbestos exposure and smoking jointly and the risk of lung cancer (with data only comparing groups exposed to asbestos with external references (group B))

\begin{tabular}{|c|c|c|c|c|c|c|}
\hline Study $(\text { ref })^{*}$ & Location & Study population & $\begin{array}{l}\text { Follow up } \\
\text { period }\end{array}$ & End point & Cases & Source of diagnosis \\
\hline Neuberger and Kundi ${ }^{30}$ & Vöcklabruck, Austria & Asbestos cement products workers & $1950-87$ & Mortality & 49 & Death certificates, medical records \\
\hline Oksa et $\mathrm{l}^{31}$ & Finland & $\begin{array}{l}\text { (1) Asbestos sprayers } \\
\text { (2) Asbestos patients } \\
\text { (3) Silicosis patients }\end{array}$ & 1967-94 & Incidence & $\begin{array}{l}\text { (1) } 3 \\
\text { (2) } 33 \\
\text { (3) } 15\end{array}$ & Cancer registry \\
\hline Elmes and Simpson ${ }^{32}$ & Belfast, Northern Ireland & Insulation workers & $1940-66$ & Mortality & 19 & Death certificates, medical records \\
\hline Hughes and Weill ${ }^{33}$ & New Orleans, USA & Asbestos cement products workers & 1969-83 & Mortality & 26 & Death certificates \\
\hline Selikoff et al ${ }^{34}$ & New Jersey, USA & Amosite asbestos factory workers & $1961-77$ & Mortality & 50 & Death certificates, medical records \\
\hline $\begin{array}{l}\text { Selikoff and } \\
\text { Hammond }^{35}\end{array}$ & $\begin{array}{l}\text { New York and New Jersey, } \\
\text { USA }\end{array}$ & Insulation workers & $1943-74$ & Mortality & 47 & Death certificates, medical records \\
\hline Hammond et al 36 & USA and Canada & Insulation workers & $1967-76$ & Mortality & 276 & Death certificates, medical records \\
\hline
\end{tabular}

ॠFirst author of most papers on study; reference is to paper from main results were obtained. 
Table 5 Case-control studies: definitions of exposure to asbestos and smoking and data used for testing of hypotheses

\begin{tabular}{|c|c|c|c|c|c|c|c|}
\hline \multirow[b]{2}{*}{ Study $(\text { ref })^{*}$} & \multirow[b]{2}{*}{ Definition and source of asbestos exposure } & \multirow[b]{2}{*}{ Definition of smoking exposure } & \multirow[b]{2}{*}{ Statistict } & \multicolumn{4}{|c|}{ Exposure group } \\
\hline & & & & $A^{-} S^{-}$ & $A^{+} S^{-}$ & $A^{-} S^{+}$ & $A^{+} S^{+}$ \\
\hline \multirow{3}{*}{ de Klerk et $a l^{13}$} & \multirow{3}{*}{ High $v$ low: work history, dust measurements } & \multirow{3}{*}{ Current or ex $<10$ years $v$ others } & Cases & 2 & 4 & 9 & 25 \\
\hline & & & Controls & 399 & 357 & 522 & 521 \\
\hline & & & RR & 1.00 & 2.24 & 3.44 & 9.57 \\
\hline \multirow[t]{3}{*}{ Martischnig et al ${ }^{14}$} & \multirow[t]{3}{*}{ Yes $v$ no: questionnaire on work history } & \multirow[t]{3}{*}{$\geqslant 15 v 0-14$ cigarettes/day } & Cases & 28 & 7 & 115 & 51 \\
\hline & & & Controls & 52 & 12 & 120 & 17 \\
\hline & & & $\mathrm{RR}$ & 1.00 & 1.08 & 1.78 & 5.57 \\
\hline \multirow{3}{*}{ Rubino et $a l^{15}$} & \multirow{3}{*}{$\begin{array}{l}\geqslant 101 v<100 \text { fibre-years: work history, dust } \\
\text { measurements }\end{array}$} & \multirow{3}{*}{ Smoker $v$ non-smoker } & Cases & 0 & 0 & 2 & 10 \\
\hline & & & Controls & 6 & 7 & 13 & 28 \\
\hline & & & RR & 0.00 & 0.00 & 1.00 & 2.32 \\
\hline \multirow[t]{6}{*}{ Pastorino et $a l^{16}$} & \multirow{3}{*}{$\begin{array}{l}\text { Yes } v \text { no: interview patients or proxies about } \\
\text { work history }\end{array}$} & \multirow[t]{6}{*}{$\geqslant 10 v 0-9$ cigarettes/day } & Cases & 7 & 2 & 66 & 31 \\
\hline & & & Controls & 69 & 7 & 119 & 31 \\
\hline & & & $\mathrm{RR}$ & 1.00 & 2.82 & 5.47 & 9.86 \\
\hline & \multirow{3}{*}{$\begin{array}{l}\text { (Data sets are in turn for people unexposed and } \\
\text { exposed to PAHs) }\end{array}$} & & Cases & 4 & 2 & 42 & 22 \\
\hline & & & Controls & 31 & 7 & 47 & 11 \\
\hline & & & $\mathrm{RR}$ & 1.00 & 2.21 & 6.93 & 15.50 \\
\hline \multirow[t]{3}{*}{ Bovenzi et $a l^{17}$} & \multirow{3}{*}{$\begin{array}{l}\text { Definite or possible } v \text { none: interview of proxies } \\
\text { about work history }\end{array}$} & \multirow[t]{3}{*}{ Ever $v$ never smoked } & Cases & 10 & 8 & 245 & 253 \\
\hline & & & Controls & 103 & 45 & 249 & 164 \\
\hline & & & $\mathrm{RR}$ & 1.00 & 1.83 & 10.13 & 15.89 \\
\hline Minowa et al $\ddagger^{18}$ & $\begin{array}{l}\text { Definite or suspected } v \text { none: interview of } \\
\text { proxies about work history }\end{array}$ & Current or ex $<10$ y $v$ others & $\mathrm{RR}$ & 1.00 & $?$ & 3.38 & 8.28 \\
\hline \multirow{3}{*}{ Kjuus $e t a l^{19}$} & \multirow{3}{*}{$\begin{array}{l}\text { Heavy or moderate } v \text { uncertain or none: } \\
\text { interview of patients about asbestos exposure }\end{array}$} & \multirow[t]{3}{*}{$\geqslant 10 v 0-9$ cigarettes/day } & Cases & 29 & 8 & 103 & 36 \\
\hline & & & Controls & 96 & 11 & 63 & 6 \\
\hline & & & $\mathrm{RR}$ & 1.00 & 2.41 & 5.41 & 19.86 \\
\hline \multirow[t]{2}{*}{ Garshick et al $\rfloor^{20}$} & \multirow[t]{2}{*}{ Yes $v$ no: work history } & \multirow[t]{2}{*}{$>50$ pack years $v$ never smoked } & $\mathrm{RR}$ & 1.00 & 1.20 & 5.68 & 6.82 \\
\hline & & & $\mathrm{RR}$ & 1.00 & 0.98 & 9.14 & 8.96 \\
\hline \multirow[t]{9}{*}{ Blot et $a l^{21-23}$} & Ever $v$ never worked in shipbuilding: interview & Current or ex $<10 \mathrm{y}$ & Cases & 50 & 11 & 313 & 84 \\
\hline & of patients or proxies about work history & $\geqslant 10$ cigarettes/day/others & Controls & 203 & 35 & 270 & 45 \\
\hline & & & $\mathrm{RR}$ & 1.00 & 1.28 & 4.71 & 7.58 \\
\hline & (Data sets are in turn for Georgia, Virginia, & & Cases & 38 & 25 & 186 & 70 \\
\hline & and Florida) & & Controls & 103 & 36 & 163 & 39 \\
\hline & & & $\mathrm{RR}$ & 1.00 & 1.88 & 3.09 & 4.87 \\
\hline & & & Cases & 17 & 5 & 208 & 65 \\
\hline & & & Controls & 110 & 18 & 224 & 54 \\
\hline & & & $\mathrm{RR}$ & 1.00 & 1.80 & 6.01 & 7.79 \\
\hline
\end{tabular}

ॠFirst author of most papers on study; reference is to paper from which main results were obtained.

$+\mathrm{RR}=$ relative risk $v \mathrm{~A}^{-} \mathrm{S}^{-}$group except where zero cases.

$\ddagger$ Cases total 96 , controls total 86 , numbers not given by exposure. Unclear from source whether relative risk estimate for $\mathrm{A}^{+} \mathrm{S}^{-}$is zero or infinite.

\Cases total 1081, two controls per case, numbers not given by exposure. Relative risks are from fitted logistic regression assuming multiplicative model, first for age $<65$, then for age $\geqslant 65$.

nosis in the reference population, it casts doubt on whether the data of Selikoff et al truly misfit. $^{34}$

Overall, the available data fit the multiplicative model well.

Tables 8-10 also include fitted values of the risks for asbestos only, smoking only, and both exposures combined. Those for asbestos only are very variable, generally smaller for casecontrol studies than others. Virtually all estimates are greater than unity confirming that exposure to asbestos increases risk of lung cancer. The variation reflects differences in extent and type of exposure to asbestos between the populations studied. All estimated risks of smoking are greater than unity. The variation reflects differences in definitions of smoking used in different studies and in smoking history for the different populations. The estimated risks for joint exposure vary, from about four in the studies by McDonald et $a l^{4}$ and Berry et al $(1971-80 \text {, men })^{1}$ to over 50 in the studies of Hammond et $a l,^{36}$ Selikoff et $a l^{35}$ and Oksa et $a^{\beta^{1}}$ (asbestos sprayers and asbestosis patients).

\section{SENSITIVITY ANALYSES}

Conclusions from group B studies were generally independent of the assumed relative risk of smoking of 7.13 for populations unexposed to asbestos. With alternative values of 3,5 , or 10 , all those studies in table 10 showing an increased risk associated with exposure to asbestos in non-smokers continued to do so, and all the studies that showed a clearly non-additive pattern of results also continued to do so. The only study where the choice of reference risk affected conclusions about multiplicativity was that of McDonald et al, as already discussed. ${ }^{24}$

ATTRIBUTABLE RISKS

Based on the fitted multiplicative model estimates, PARs for background exposure to asbestos only, smoking only, and their joint effect were calculated, firstly among those exposed to both agents, and secondly among the whole population studied. Table 11 presents means of these estimates separately by study type. The PAR estimates varied considerably between studies (data not shown) due to differences between studies in the extent of exposure to asbestos and in the definition of the smoking categories. For group B cohortoccupational studies where the estimated effect of asbestos was relatively high-the PAR for background was relatively low and that for joint exposure relatively high. The PAR for asbestos only was also similar to that for smoking only, whereas in case-control and group A studies it was substantially lower.

\section{Discussion}

LIMITATIONS OF THE EVIDENCE

Effects of asbestos are difficult to study, some studies representing years of dedicated work. However, various limitations affect many or all of the studies, including: (a) Reliance on death certificate data, known to be inaccurate ${ }^{37}$ (for 
Table 6 Cohort and occupational studies (group A): definitions of asbestos exposure and smoking and data used for testing of hypotheses

\begin{tabular}{|c|c|c|c|c|c|c|c|}
\hline \multirow[b]{2}{*}{ Study $(\text { ref })^{*}$} & \multirow[b]{2}{*}{ Definition and source of asbestos exposure } & \multirow[b]{2}{*}{ Definition of smoking exposure } & \multirow[b]{2}{*}{ Statistict } & \multicolumn{4}{|c|}{ Exposure group } \\
\hline & & & & $A^{-} S^{-}$ & $A^{+} S^{-}$ & $A^{-} S^{+}$ & $A^{+} S^{+}$ \\
\hline \multirow[t]{4}{*}{ McDonald et a ${ }^{4}$} & \multirow{4}{*}{$\begin{array}{l}\geqslant 60 v<60 \text { million particles per cubic } \\
\text { foot } \times \text { years: work history and dust } \\
\text { measurements }\end{array}$} & \multirow[t]{4}{*}{ Ever $v$ never smoked cigarettes } & $\mathrm{O}$ & 10 & 11 & 132 & 146 \\
\hline & & & $\mathrm{E}$ & 27.03 & 18.03 & 80.00 & 87.43 \\
\hline & & & SMR & 0.37 & 0.61 & 1.65 & 1.67 \\
\hline & & & RR & 1.00 & 1.65 & 4.46 & 4.51 \\
\hline \multirow[t]{2}{*}{ Cheng and Kong $\ddagger^{25}$} & \multirow[t]{2}{*}{ Yes $v$ no: work history and dust measurements } & \multirow[t]{2}{*}{ Cigarette smoker $v$ non-smoker } & Rate & 38.3 & 208.2 & 60.3 & 334.2 \\
\hline & & & $\mathrm{RR}$ & 1.00 & 5.44 & 1.57 & 8.73 \\
\hline \multirow[t]{3}{*}{ Zhu and Wang ${ }^{26}$} & \multirow[t]{3}{*}{ Yes $v$ no: work history and dust measurements } & \multirow[t]{3}{*}{ Smoker $v$ non-smoker } & $\mathrm{O}$ & 4 & 15 & 11 & 27 \\
\hline & & & Man-years & 42502 & 42218 & 63714 & 25933 \\
\hline & & & RR & 1.00 & 3.78 & 1.83 & 11.06 \\
\hline \multirow[t]{8}{*}{ Berry et al $\$(1971-80)^{1}$} & \multirow[t]{2}{*}{ Severe $v$ low to moderate: work history } & \multirow[t]{8}{*}{ Ever $v$ never smoked cigarettes } & $\mathrm{O}$ & 1 & 0 & 20 & 43 \\
\hline & & & ES & 0.10 & 0.06 & 12.36 & 15.88 \\
\hline & \multirow[t]{6}{*}{ (Data sets are in turn for men and women) } & & SMR & 1.50 & 0 & 1.73 & 2.90 \\
\hline & & & $\mathrm{RR}$ & 1.00 & 0 & 1.15 & 1.93 \\
\hline & & & $\mathrm{O}$ & 0 & 3 & 0 & 12 \\
\hline & & & ES & 0.04 & 0.20 & 0.41 & 2.52 \\
\hline & & & SMR & 0 & 2.25 & 0 & 5.10 \\
\hline & & & RR & 0 & 1.00 & 0 & 2.26 \\
\hline \multirow[t]{4}{*}{ Acheson $e t a l^{7}$} & \multirow{4}{*}{$\begin{array}{l}\text { Medium or heavy } v \text { background: } \\
\text { work history and dust measurements }\end{array}$} & \multirow[t]{4}{*}{ Ever $v$ never smoked } & $\mathrm{O}$ & 0 & 1 & 0 & 21 \\
\hline & & & $\mathrm{E}$ & 0.40 & 1.10 & 2.60 & 9.00 \\
\hline & & & SMR & 0 & 0.91 & 0 & 2.33 \\
\hline & & & RR & 0 & 1.00 & 0 & 2.57 \\
\hline \multirow[t]{4}{*}{ Meurman et a $2^{8}$} & \multirow[t]{4}{*}{ Heavy $v$ moderate: work history } & \multirow[t]{4}{*}{ Cigarette smoker $v$ non-smoker } & $\mathrm{O}$ & 1 & 1 & 12 & 41 \\
\hline & & & $\mathrm{E}$ & 1.72 & 2.08 & 3.29 & 11.45 \\
\hline & & & SMR & 0.58 & 0.48 & 3.65 & 3.58 \\
\hline & & & $\mathrm{RR}$ & 1.00 & 0.83 & 6.27 & 6.16 \\
\hline \multirow[t]{3}{*}{ Hilt et $a l^{29}$} & \multirow[t]{3}{*}{ Exposed $v$ population controls: work history } & \multirow[t]{3}{*}{ Ever $v$ never smoked } & $\mathrm{O}$ & 7 & 0 & 111 & 9 \\
\hline & & & Rate & 1.90 & 0 & 11.10 & 47.80 \\
\hline & & & $\mathrm{RR}$ & 1.00 & 0 & 5.84 & 25.20 \\
\hline
\end{tabular}

^First author of most papers on study; reference is to paper from which main results were obtained.

$+\mathrm{RR}=$ relative risk (to base $\mathrm{A}^{-} \mathrm{S}^{-}$unless zero cases); $\mathrm{O}=$ observed cases; $\mathrm{E}=$ expected; $\mathrm{ES}=$ expected adjusted for smoking; $\mathrm{SMR}=$ standardised mortality rate.

$\ddagger$ Man-years and numbers of cases not given, death rates per 100000 per year age standardised.

\SMR and RR calculated by dividing smoking adjusted expected values by 0.15 for $\mathrm{S}^{-}$and 1.07 for $\mathrm{S}^{+}$to make them comparable to the same reference population.

studies with an external reference this is inevitable, the reference data being based on death certification); (b) difficulties in assessment of exposure to asbestos, which is often only an educated guess (dust measurements, even where available, are never complete); (c) inaccuracies in smoking history, no studies validating self reported non-smoking by cotinine measurements; (d) inconsistent classification of smoking, with the unexposed group often including light smokers, ex-smokers, or non-cigarette smokers; (e) failure to account for other factors associated with lung cancer; $(f)$ reliance on data obtained from proxy respondents; and $(g)$ small numbers of lung cancers.

Three limitations seem most serious. Firstly, the sparsity of lung cancers in some studies leads to unreliable risk estimates, particularly in non-smokers.

Secondly, failure to account for confounding by other lung carcinogens means increased risks in groups that are exposed to asbestos may not result totally from asbestos. For example, some miners may have high radon exposure, railway workers may have increased exposure to coal dust and diesel, and shipyard work may involve exposures other than asbestos.

Thirdly, misclassification of some current or ex-smokers as non-smokers may affect estimates of the effect of asbestos in non-smokers. However, provided a true multiplicative relation exists, it should still be seen after misclassification of smoking, if the misclassification is independent of exposure to asbestos. (Misclassification of exposure to asbestos, which is independent of smoking habits, will also not upset a multiplicative relation.)

Provided a multiplicative relation exists, it should also still be seen regardless of the smok- ing definition used in a particular study. However, differences in definition will affect the magnitude of the estimated effect of smoking and the proportion of deaths attributed to smoking and its interaction with asbestos.

A true multiplicative relation may not be observed exactly in practice because average exposure to asbestos may differ between non-smokers and smokers exposed to asbestos (or, conversely, because the average amount smoked may differ between smokers exposed and unexposed to asbestos). The model fitting conducted is based on data subdivided into four groups. In principle, it is better to conduct a regression analysis including terms for extent and duration of smoking and of exposure to asbestos and then see whether additional interaction terms are significant, so implying inadequacy of the multiplicative model. Data from the study by Garshick et al were in fact analysed in this way, ${ }^{20}$ with no interaction detected.

PREVIOUS REVIEWS

In 1977, Saracci ${ }^{3}$ reviewed five studies, and concluded that the multiplicative model was "more plausible" than the additive model, although the data "do not allow a definitive discrimination". Later, Berry et al suggested that the relative risk of lung cancer from asbestos might be six times higher for non-smokers than smokers, but noted "uncertainty on the accuracy of this figure because of possible biases and sampling variation."

Steenland and Thun ${ }^{6}$ in 1986, considered that only four studies ${ }^{12435}{ }^{36}$ provided sufficient information to evaluate interaction and that the data were "contradictory". For the study by Berry et al, their conclusion of departure from multiplicativity and also of no departure from 
the additivity disagrees both with our analyses and those by the original authors. ${ }^{1}$

An updated review by Saracci ${ }^{4}$ in 1987 that considered data from 11 studies classified the interaction on a scoring system ranging from "more than multiplicative", where the risk for $\mathrm{A}^{+} \mathrm{S}^{+}$was at least $25 \%$ more than that predicted by the multiplicative model, to "less than additive", where it was at most $75 \%$ of that predicted by the additive model. They noted that "a somewhat variable pattern of interaction has been observed between asbestos and tobacco smoking", which may "reflect real differences stemming from the fact that both asbestos and smoking act at different stages of the carcinogenic process." Similar conclusions were reached later by Saracci and Boffetta ${ }^{5}$ and by Vainio and Boffetta ${ }^{7}$ based on 13 studies. None of these papers included results of formal tests that the "variable pattern" of interaction actually was significant.

The same is true for the 1999 review by Erren et $a l^{2}{ }^{2}$ which used data from 10 studies reviewed here to estimate the synergy index, the relative excess risk due to interaction, and the PAR due to interaction. The authors concluded that "one-third of cancer cases among smokers who were exposed to asbestos can be attributed to the synergistic behavior of the two carcinogens." The authors used the

Table 7 Cohort and occupational studies (group B): definitions of asbestos exposure and smoking and data used for testing of hypotheses

\begin{tabular}{|c|c|c|c|c|c|c|c|}
\hline \multirow[b]{2}{*}{ Study $(r e f)^{*}$} & \multirow{2}{*}{$\begin{array}{l}\text { Definition and source of asbestos } \\
\text { exposure }\end{array}$} & \multirow[b]{2}{*}{ Definition of smoking exposure } & \multirow[b]{2}{*}{ Statistict } & \multicolumn{4}{|c|}{ Exposure group } \\
\hline & & & & $A^{-} S^{-}$ & $A^{+} S^{-}$ & $A^{-} S^{+}$ & $A^{+} S^{+}$ \\
\hline Neuberger and Kundi $\neq^{30}$ & $\begin{array}{l}\text { All workers: work history and } \\
\text { dust measurements }\end{array}$ & Cigarettes/day smoked & & & & & \\
\hline \multirow[t]{4}{*}{ McDonald et a ${ }^{4}$} & $\geqslant 60$ million particles per cubic & \multirow[t]{4}{*}{ Ever $v$ never smoked cigarettes } & $\mathrm{O}$ & & 11 & & 146 \\
\hline & \multirow{3}{*}{$\begin{array}{l}\text { foot } \times \text { years: work history and } \\
\text { dust measurements }\end{array}$} & & $\mathrm{E}$ & & 18.03 & & 87.43 \\
\hline & & & SMR & {$[0.15]$} & 0.61 & {$[1.07]$} & 1.67 \\
\hline & & & RR & 1.00 & 4.07 & [7.13] & 11.13 \\
\hline \multirow[t]{4}{*}{ Berry et al $(1960-70)^{1}$} & \multirow[t]{4}{*}{ Severe: work history } & \multirow[t]{4}{*}{ Ever $v$ never smoked cigarettes } & $\mathrm{O}$ & & 1 & & 43 \\
\hline & & & ES & & 0.2 & & 14.2 \\
\hline & & & SMR & {$[0.15]$} & 0.75 & [1.07] & 3.24 \\
\hline & & & $\mathrm{RR}$ & 1.00 & 5.00 & [7.13] & 21.60 \\
\hline \multirow{8}{*}{ Berry et al $(1971-80)^{1}$} & \multirow{8}{*}{ Severe: work history } & \multirow[t]{3}{*}{ Ever $v$ never smoked cigarettes } & $\mathrm{O}$ & & 0 & & 43 \\
\hline & & & ES & & 0.06 & & 15.88 \\
\hline & & & SMR & [0.15] & 0 & {$[1.07]$} & 2.90 \\
\hline & & (men) & $\mathrm{RR}$ & 1.00 & 0 & {$[7.13]$} & 19.33 \\
\hline & & \multirow[t]{4}{*}{ (women) } & $\mathrm{O}$ & & 3 & & 12 \\
\hline & & & ES & & 0.20 & & 2.52 \\
\hline & & & SMR & {$[0.15]$} & 2.25 & {$[1.07]$} & 5.10 \\
\hline & & & $\mathrm{RR}$ & 1.00 & 15.00 & [7.13] & 33.97 \\
\hline \multirow[t]{4}{*}{ Acheson $e t a l^{7}$} & & Ever $v$ never smoked & $\mathrm{O}$ & & 1 & & 21 \\
\hline & and dust measurements & & $\mathrm{E}$ & & 1.10 & & 9.00 \\
\hline & & & SMR & {$[0.15]$} & 0.91 & [1.07] & 2.33 \\
\hline & & & $\mathrm{RR}$ & 1.00 & 6.07 & [7.13] & 15.53 \\
\hline Oksa $e t a l^{11}$ & Study group: medical interview & Ever smoked $v$ never smoked & $\mathrm{O}$ & & 0 & & 3 \\
\hline & & & $\mathrm{E}$ & & 0.10 & & 0.27 \\
\hline & & & SIR & {$[0.15]$} & 0 & {$[1.07]$} & 11.22 \\
\hline & & (asbestos sprayers) & RR & 1.00 & 0 & {$[7.13]$} & 74.77 \\
\hline & & (patients with asbestosis) & $\mathrm{O}$ & & 0 & & 33 \\
\hline & & & $\mathrm{E}$ & & 0.60 & & 2.69 \\
\hline & & & SIR & {$[0.15]$} & 0 & {$[1.07]$} & 12.26 \\
\hline & & & $\mathrm{RR}$ & 1.00 & 0 & [7.13] & 81.72 \\
\hline & & (patients with silicosis) & $\mathrm{O}$ & & 0 & & 15 \\
\hline & & & $\mathrm{E}$ & & 0.10 & & 4.48 \\
\hline & & & SIR & {$[0.15]$} & 0 & {$[1.07]$} & 3.35 \\
\hline & & & $\mathrm{RR}$ & 1.00 & 0 & [7.13] & 22.34 \\
\hline Meurman $e t a l^{8}$ & Heavy: work history & Cigarette smoker $v$ non-smoker & $\mathrm{O}$ & & 1 & & 41 \\
\hline & & & $\mathrm{E}$ & & 2.08 & & 11.45 \\
\hline & & & SIR & {$[0.15]$} & 0.48 & {$[1.07]$} & 3.58 \\
\hline & & & $\mathrm{RR}$ & 1.00 & 3.21 & [7.13] & 23.87 \\
\hline Elmes and Simpson $\S^{32}$ & Study group: inferred from & Smoker $v$ non-smoker & $\mathrm{O}$ & & 0 & & 19 \\
\hline & nature of population studied & & ES & & Low & & 1.20 \\
\hline & & & SMR & {$[0.15]$} & 0 & [1.07] & 16.94 \\
\hline & & & $\mathrm{RR}$ & 1.00 & 0 & [7.13] & 112.94 \\
\hline Hughes and Weill| $\left.\right|^{33}$ & Study group: work history and & Ever $v$ never smoked & $\mathrm{O}$ & & 0 & & 26 \\
\hline & dust measurements & & $\mathrm{E}$ & & Low & & $<15.4$ \\
\hline & & & SMR & [0.15] & 0 & {$[1.07]$} & $\simeq 2$ \\
\hline & & & $\mathrm{RR}$ & 1.00 & 0 & {$[7.13]$} & $\simeq 13$ \\
\hline Selikoff et al ${ }^{34}$ & Study group: inferred from & Ever $v$ never smoked cigarettes & $\mathrm{O}$ & & 5 & & 45 \\
\hline & nature of population studied & & ES & & 0.2 & & 9.6 \\
\hline & & & SMR & {$[0.15]$} & 3.75 & {$[1.07]$} & 5.02 \\
\hline & & & $\mathrm{RR}$ & 1.00 & 25.00 & [7.13] & 33.44 \\
\hline Selikoff and Hammond ${ }^{35}$ & Study group: inferred from & Ever $v$ never smoked cigarettes & $\mathrm{O}$ & & 2 & & 45 \\
\hline & nature of population studied & & $\mathrm{E}$ & & 1.58 & & 4.07 \\
\hline & & & SMR & {$[0.15]$} & 1.27 & {$[1.07]$} & 11.06 \\
\hline & & & $\mathrm{RR}$ & 1.00 & 8.44 & [7.13] & 73.71 \\
\hline Hammond et a ${ }^{\beta 6}$ & Study group: inferred from & Ever $v$ never smoked cigarettes & $\mathrm{O}$ & & 8 & & 268 \\
\hline & nature of population studied & & Rate & 11.3 & 58.4 & 122.6 & 601.6 \\
\hline & & & $\mathrm{RR}$ & 1.00 & 5.17 & 10.85 & 53.24 \\
\hline
\end{tabular}

*First author of most papers on study; reference is to paper from which main results were obtained.

$+\mathrm{RR}=$ relative risk (to base $\mathrm{A}^{-} \mathrm{S}^{-}$), $\mathrm{O}=$ observed cases, $\mathrm{E}=$ expected, $\mathrm{ES}=$ expected adjusted for smoking, $\mathrm{SMR}=$ standardised mortality rate, $\mathrm{SIR}=$ standardised incidence rate.

$¥$ The authors presented a graph showing that the observed number of deaths was close to a smoking-adjusted expected for non-smokers and for smokers of 10,25 , 40 and 50 cigarettes/day.

SOnly five non-smokers at risk.

TThe authors noted that no deaths were in never smokers, and that for the whole population 26 deaths occurred against 15.4 expected.

Values in [ ] are assumed values taken from data for British doctors. ${ }^{10}$ 
terms synergy and interaction as describing departure from an additive model.

\section{Conclusions}

Our review clearly shows that exposure to asbestos increases the risk of lung cancer in non-smokers, and that the joint relation of asbestos and smoking to risk is much better described by a multiplicative than by an additive model. The fit to the multiplicative model is generally good, discrepancies noted for two studies (McDonald $e t a l^{24}$ and Selikoff et $a \beta^{34}$ ) seem to be more apparent than real.

The increased risk from smoking varies by amount of cigarettes smoked, duration of smoking, inhalation, and product smoked, and the definition of the non-smoking denominator used. The increase for asbestos also depends on many factors, not only extent and duration of exposure, but also type of asbestos and

Table 8 Summary statistics for case-control studies

\begin{tabular}{|c|c|c|c|c|c|c|c|}
\hline \multirow[b]{2}{*}{ Study $(\text { ref })^{\star}$} & \multirow{2}{*}{$\begin{array}{l}\text { Asbestos RR (95\% CI) } \\
\text { in non-smokers }\end{array}$} & \multirow{2}{*}{$\begin{array}{l}\text { Test of } \\
\text { additivity } U\end{array}$} & \multirow{2}{*}{$\begin{array}{l}\text { Test of multiplicativity } V \\
(95 \% \mathrm{CI})\end{array}$} & \multirow[b]{2}{*}{ Deviance } & \multicolumn{3}{|c|}{ Fitted effects (multiplicative model) } \\
\hline & & & & & $A$ & $S$ & $A S$ \\
\hline de Klerk et $a l^{13}$ & $1.90(0.62$ to 5.85$) \dagger$ & 4.90 & $1.25(0.19$ to 8.08$)$ & 0.05 & 2.68 & 4.00 & 10.75 \\
\hline Martischnig et $a l^{14}$ & $1.08(0.38$ to 3.06$)$ & 3.71 & $2.89(0.87$ to 9.62$)$ & 3.08 & 2.40 & 2.21 & 5.29 \\
\hline Rubino et $a l^{15}$ & Undefined & 1.32 & Undefined & 0.00 & 2.32 & $\infty$ & $\infty$ \\
\hline Pastorino et $a l^{16}$ & $2.52(0.79$ to 9.10$) \ddagger$ & & & & & & \\
\hline No PAHs & & 2.57 & $0.64(0.10$ to 4.06$)$ & 0.21 & 1.88 & 5.03 & 9.46 \\
\hline PAHs & & 7.36 & $1.01(0.13$ to 7.94$)$ & 0.00 & 2.23 & 6.95 & 15.52 \\
\hline Bovenzi et $a l^{17}$ & 1.83 (0.64 to 4.95$)$ & 4.92 & $0.86(0.31$ to 2.39$)$ & 0.08 & 1.58 & 9.50 & 15.05 \\
\hline Minowa et als ${ }^{18}$ & - & - & - & - & - & - & - \\
\hline Kjuus et al ${ }^{19}$ & $2.41(0.89$ to 6.55$)$ & 13.04 & $1.52(0.39$ to 5.93$)$ & 0.38 & 3.04 & 5.77 & 17.54 \\
\hline Garshick et a $\|^{20}$ & - & - & - & - & & & \\
\hline Age $<65$ & & & & & 1.20 & 5.68 & 6.82 \\
\hline Age $\geqslant 65$ & & & & & 0.98 & 9.14 & 8.96 \\
\hline \multicolumn{8}{|l|}{ Blot et al: ${ }^{21-23}$} \\
\hline Georgia & $1.28(0.61$ to 2.69$)$ & 2.60 & $1.26(0.54$ to 2.93$)$ & 0.30 & 1.53 & 4.90 & 7.49 \\
\hline Virginia & $1.88(1.00$ to 3.54$)$ & 0.89 & $0.84(0.39$ to 1.81$)$ & 0.21 & 1.67 & 2.93 & 4.89 \\
\hline Florida & $1.80(0.59$ to 5.48$)$ & 0.98 & $0.72(0.22$ to 2.36$)$ & 0.28 & 1.35 & 5.63 & 7.58 \\
\hline
\end{tabular}

$\star$ First author of most papers on study; reference is to paper from which main results were obtained.

†Relative risk and $95 \%$ CI from matched analysis as given by authors.

¥Adjusted for exposure to polycyclic aromatic hydrocarbons (PAHs).

\Summary statistics cannot be estimated for this study.

TThe authors did not present data separated by smoking and asbestos exposure, only results of logistic regression, from which fitted effects are shown. Smoking effects are for $>50$ pack-years.

Table 9 Summary statistics for cohort and occupational studies (group A)

\begin{tabular}{|c|c|c|c|c|c|c|c|}
\hline \multirow[b]{2}{*}{ Study $(\text { ref })^{\star}$} & \multirow[b]{2}{*}{$\begin{array}{l}\text { Asbestos RR (95\% CI) } \\
\text { in non-smokers }\end{array}$} & \multirow[b]{2}{*}{$\begin{array}{l}\text { Test of } \\
\text { additivity } U\end{array}$} & \multirow[b]{2}{*}{$\begin{array}{l}\text { Test of multiplicativity } V \\
(95 \% \mathrm{CI})\end{array}$} & \multirow[b]{2}{*}{ Deviance } & \multicolumn{3}{|c|}{ Fitted effects (multiplicative model) } \\
\hline & & & & & $A$ & $S$ & $A S$ \\
\hline McDonald et a ${ }^{24}$ & 1.65 (0.64 to 4.33$)$ & -0.60 & $0.61(0.25$ to 1.49$)$ & 1.16 & 1.05 & 3.54 & 3.71 \\
\hline Cheng and Kong ${ }^{25}$ & 5.44 & 2.72 & 0.98 & - & - & - & - \\
\hline Zhu and Wang ${ }^{26}$ & $3.78(1.25$ to 11.4$)$ & 6.45 & $1.60(0.43$ to 5.90$)$ & 0.47 & 5.33 & 2.65 & 14.13 \\
\hline \multicolumn{8}{|l|}{ Berry et al (1971-80): ${ }^{1}$} \\
\hline Men & & 1.78 & $\infty$ & 1.37 & 1.61 & 2.33 & 3.76 \\
\hline Women & & 1.26 & Undefined & 0.00 & $\infty$ & 2.26 & $\infty$ \\
\hline Combined & $1.62(0.13$ to 8.51$)$ & & & & & & \\
\hline Acheson et $a l^{7}$ & $\infty$ & 1.57 & Undefined & 0.00 & $\infty$ & 2.57 & $\infty$ \\
\hline Meurman et a $2^{8}$ & $0.83(0.01$ to 64.6$)$ & 0.06 & $1.19(0.07$ to 20.4$)$ & 0.01 & 0.97 & 6.87 & 6.69 \\
\hline Hilt et a ${ }^{29}$ & 0.00 & 20.32 & $\infty$ & 0.54 & 4.17 & 6.08 & 25.36 \\
\hline
\end{tabular}

^First author of most papers on study; reference is to paper from which main results were obtained.

†Numbers of cases not given so $95 \% \mathrm{CI}$, deviance, and fitted effects not available.

Table 10 Summary statistics for cohort and occupational studies (group B)

\begin{tabular}{|c|c|c|c|c|c|c|c|}
\hline \multirow[b]{2}{*}{ Study $(\text { ref })^{*}$} & \multirow{2}{*}{$\begin{array}{l}\text { Asbestos RR }(95 \% \text { CI) } \\
\text { in non-smokers }\end{array}$} & \multirow{2}{*}{$\begin{array}{l}\text { Test of } \\
\text { additivity } U\end{array}$} & \multirow{2}{*}{$\begin{array}{l}\text { Test of multiplicativity } V \\
(95 \% \mathrm{CI})\end{array}$} & \multirow[b]{2}{*}{ Deviance } & \multicolumn{3}{|c|}{ Fitted effects (multiplicative model) } \\
\hline & & & & & $A$ & $S$ & $A S$ \\
\hline Neuberger and Kundi $\dagger^{30}$ & $\simeq 1.00$ & - & - & - & - & - & - \\
\hline McDonald et al ${ }^{4}$ & 4.07 (2.03 to 7.29$)$ & 0.93 & $0.38(0.21$ to 0.79$)$ & 10.12 & 1.63 & [7.13] & 11.64 \\
\hline Berry et al $(1960-70)^{1}$ & $5.00(0.13$ to 27.9$)$ & 10.47 & $0.61(0.10$ to 25.7$)$ & 0.25 & 3.06 & [7.13] & 21.80 \\
\hline \multicolumn{8}{|l|}{ Berry et al (1971-80): ${ }^{1}$} \\
\hline Men & & & $\infty$ & 0.16 & 2.70 & [7.13] & 19.24 \\
\hline Women & & & $0.32(0.09$ to 1.75$)$ & 3.51 & 5.52 & [7.13] & 39.40 \\
\hline Combined & 11.5 (2.38 to 33.7$)$ & 2.65 & & & & & \\
\hline Acheson et $a l^{27}$ & $6.06(0.15$ to 33.8$)$ & 3.33 & $0.36(0.06$ to 14.7$)$ & 0.36 & 2.25 & {$[7.13]$} & 16.02 \\
\hline \multicolumn{8}{|l|}{ Oksa et al: $:^{31}$} \\
\hline Asbestos sprayers & 0.00 & 68.64 & $\infty$ & 0.16 & 9.96 & [7.13] & 71.04 \\
\hline Patients with asbestosis & 0.00 & 75.59 & $\infty$ & 1.03 & 11.11 & [7.13] & 79.20 \\
\hline Patients with silicosis & 0.00 & 16.21 & $\infty$ & 0.52 & 3.03 & [7.13] & 21.60 \\
\hline Meurman et al ${ }^{8}$ & $3.21(0.08$ to 17.8$)$ & 14.53 & $1.05(0.18$ to 46.4$)$ & 0.00 & 3.34 & {$[7.13]$} & 23.85 \\
\hline Elmes and Simpson ${ }^{32}$ & 0.00 & 106.8 & $\infty$ & 0.00 & 15.83 & [7.13] & 112.9 \\
\hline Hughes and Weill ${ }^{33}$ & 0.00 & $\simeq 7$ & $\infty$ & Low & $\simeq 2$ & [7.13] & $\simeq 14$ \\
\hline Selikoff $e t a l^{34}$ & $25.00(8.12$ to 58.3$)$ & 2.31 & $0.19(0.07$ to 0.61$)$ & 15.85 & 5.10 & [7.13] & 36.39 \\
\hline Selikoff and Hammond ${ }^{35}$ & $8.44(1.02$ to 30.5$)$ & 59.14 & $1.22(0.32$ to 10.4$)$ & 0.08 & 10.24 & {$[7.13]$} & 73.01 \\
\hline Hammond et a ${ }^{36}$ & $5.71(1.56$ to 14.6$)$ & 38.22 & $0.95(0.47$ to 2.21$)$ & 0.02 & 4.91 & [10.85] & 53.37 \\
\hline
\end{tabular}

^First author of most papers on study; reference is to paper from which main results were obtained.

†Most summary statistics cannot be estimated from the graphical data presented.

Values in [ ] are assumed values taken from external data. 
Table 11 Percentage attributable risks from smoking and asbestos exposure

\begin{tabular}{|c|c|c|c|c|c|}
\hline & \multirow[b]{2}{*}{ Cases } & \multicolumn{4}{|c|}{$\%$ Attributable to } \\
\hline & & Background & $\begin{array}{l}\text { Asbestos } \\
\text { only }\end{array}$ & $\begin{array}{l}\text { Smoking } \\
\text { only }\end{array}$ & $\begin{array}{l}\text { Both } \\
\text { factors }\end{array}$ \\
\hline \multicolumn{6}{|l|}{ Among those exposed to both agents: } \\
\hline Case-control* ${ }^{\star}$ & 647 & 10.4 & 10.0 & 41.1 & 38.4 \\
\hline Cohort/occupational (group A)† & 299 & 11.4 & 20.5 & 31.9 & 36.2 \\
\hline Cohort/occupational (group B) $\ddagger$ & 452 & 2.7 & 11.2 & 16.8 & 69.3 \\
\hline \multicolumn{6}{|l|}{ Among the whole population: } \\
\hline Case-control ${ }^{\star}$ & 2193 & 24.0 & 5.0 & 55.7 & 15.4 \\
\hline Cohort/occupational (group A) $\dagger$ & 639 & 18.0 & 20.8 & 40.4 & 20.9 \\
\hline Cohort/occupational (group B) $\ddagger$ & 468 & 3.0 & 12.6 & 16.5 & 68.0 \\
\hline
\end{tabular}

${ }^{\star}$ Means for the 10 studies (or substudies) in table 4 except Minowa et $l^{18}$ and Garshick et al. ${ }^{20}$ †Means for the seven studies (or substudies) in table 5 except Cheng and Kong. ${ }^{25}$

$\ddagger$ Means for the seven studies (or substudies) Berry et al (1960-70), ${ }^{1}$ Oksa et al (three groups), ${ }^{31}$ Selikoff $e t ~ a l,{ }^{34}$ Selikoff and Hammond, ${ }^{35}$ and Hammond et al. ${ }^{36}$

nature of exposure. This largely explains why increases in risk for certain occupational groups are larger than for others, although differences in occupational exposures to other carcinogens might contribute.

Multiplicativity implies that attributable risks for smoking and for asbestos may exceed the total risk. Thus, the data of Hammond et $a l,{ }^{36}$ with risk of lung cancer increased about fivefold for asbestos and 10-fold for smoking, taken at face value and ignoring confounding by other exposures, implies that among the insulation workers who smoked, about $90 \%$ of their lung cancers could have been avoided by not smoking, and about $80 \%$ could have been avoided by not being insulation workers.

I thank John Fry for helpful comments on this review and for assistance in carrying out the statistical tests described. I also thank Pauline Wassell and Diane Morris for their diligent and accurate word processing. Funding for this work was from Philip Morris Europe. The views expressed are those of the author and not necessarily of any other person or organisation.

1 Berry G, Newhouse ML, Antonis P. Combined effect of asbestos and smoking on mortality from lung cancer and mesothelioma in factory workers. $\mathrm{Br} \mathscr{f}$ Ind $\mathrm{Med}$ $1985 ; 42: 12-8$

2 Erren TC, Jacobsen M, Piekarski C. Synergy between asbestos and smoking on lung cancer risks. Epidemiology 1999;10:405-11.

3 Saracci R. Asbestos and lung cancer: an analysis of the epidemiological evidence on the asbestos-smoking interaction. Int 7 Cancer 1977;20:323-31.

4 Saracci R. The interactions of tobacco smoking and other agents in cancer etiology. Epidemiol Rev 1987;9:175-93.

5 Saracci R, Boffetta P. Interactions of tobacco smoking with other causes of lung cancer. In: Samet JM. Epidemiology of lung cancer: lung biology in health and disease 1994;74:46593.

6 Steenland K, Thun M. Interaction between tobacco smoking and occupational exposures in the causation of lung ing and occupational exposures in the
cancer. F Occup Med 1986;28:110-8.

cancer. F Occup Med 1986;28:110-8.
7 Vainio H, Boffetta P. Mechanisms of the combined effect of asbestos and smoking in the etiology of lung cancer. Scand $f$ Work Environ Health 1994;20:235-42.

8 Lee BW, Wain JC, Kelsey KT, et al. Association of cigarette smoking and asbestos exposure with location and histology of lung cancer. Am F Respir Crit Care Med 1998;157:748 55.

9 Gardner MJ, Altman DG, eds. Statistics with confidence. London: BMJ, 1989.

10 Doll R, Peto R, Wheatley K, et al. Mortality in relation to smoking: 40 years' observations on male British doctors. BMF 1994;309:901-11.
11 Fleiss JL, Gross AJ. Meta-analysis in epidemiology, with special reference to studies of the association between exposure to environmental tobacco smoke and lung cancer: a critique. F Clin Epidemiol 1991;44:127-39.

12 Rothman KJ, Greenland S. Modern epidemiology, 2nd ed. Philadelphia, PA: Lippincott-Raven, 1998:738.

13 de Klerk NH, Musk AW, Armstrong BK, et al. Smoking, exposure to crocidolite, and the incidence of lung cancer and asbestosis. Br f Ind Med 1991;48:412-7.

14 Martischnig KM, Newell DJ, Barnsley WC, et al. Unsuspected exposure to asbestos and bronchogenic carcinoma. BMF 1977;1:746-9.

15 Rubino GF, Piolatto G, Newhouse ML, et al. Mortality of chrysotile asbestos workers at the Balangero Mine, Northern Italy. Br F Ind Med 1979;36:187-94.

16 Pastorino U, Berrino F, Gervasio A, et al. Proportion of lung cancers due to occupational exposure. Int $\mathcal{f}$ Cancer 1984;33:231-7.

17 Bovenzi M, Stanta G, Antiga G, et al. Occupational exposure and lung cancer risk in a coastal area of northeastern Italy. Int Arch Occup Environ Health 1993;65: 35-41.

18 Minowa M, Hatano S, Ashizawa M, et al. A case-control study of lung cancer with special reference to asbestos exposure. Environ Health Perspect 1991;94:39-42.

19 Kjuus H, Skjaerven R, Langard S, et al. A case-referent study of lung cancer, occupational exposures and smoking: II role of asbestos exposure. Scand $\mathcal{F}$ Work Environ Health 1986;12:203-9.

20 Garshick E, Schenker MB, Muñoz A, et al. A case-control study of lung cancer and diesel exhaust exposure in railroad workers. Am Rev Respir Dis 1987;135:1242-8.

21 Blot WJ, Harrington JM, Toledo A, et al. Lung cancer after employment in shipyards during World War II. N Engl f Med 1978;299:620-4.

22 Blot WJ, Morris LE, Stroube R, et al. Lung and laryngeal cancers in relation to shipyard employment in coastal Virginia. $\mathcal{F}$ Natl Cancer Inst 1980;65:571-5.

23 Blot WJ, Davies JE, Morris Brown L, et al. Occupation and the high risk of lung cancer in Northeast Florida. Cancer 1982;50:364-71.

24 McDonald JC, Liddell FDK, Dufresne A, et al. The 18911920 birth cohort of Quebec chrysotile miners and millers: mortality 1976-88. Br f Ind Med 1993;50:1073-81.

25 Cheng W-N, Kong J. A retrospective mortality cohort study of chrysotile asbestos products workers in Tianjin 197287. Environ Res 1992;59:271-8

$26 \mathrm{Zhu} \mathrm{H}$, Wang Z. Study of occupational lung cancer in asbestos factories in China. Br F Ind Med 1993;50:103942.

27 Acheson ED, Gardner MJ, Winter PD, et al. Cancer in a factory using amosite asbestos. Int f Epidemiol 1984;13:310 .

28 Meurman LO, Pukkala E, Hakama M. Incidence of cancer among anthophyllite asbestos miners in Finland. Occup Environ Med 1994;51:421-5.

29 Hilt B, Langård S, Andersen A, et al. Asbestos exposure, smoking habits, and cancer incidence among production and maintenance workers in an electrochemical plant. $\mathrm{Am}$ f Ind Med 1985;8:565-77.

30 Neuberger $M$, Kundi $M$. Individual asbestos exposure: smoking and mortality: a cohort study in the asbestos cement industry. Br f Ind Med 1990;47:615-20.

31 Oksa P, Pukkala E, Karjalainen A, et al. Cancer incidence and mortality among Finnish asbestos sprayers and in asbestosis and silicosis patients. Am f Ind Med 1997;31: 693-8.

32 Elmes PC, Simpson MJC. Insulation workers in Belfast. 3. Mortality 1940-66. Br F Ind Med 1971;28:226-36.

33 Hughes JM, Weill H. Asbestosis as a precursor of asbestos related lung cancer: results of a prospective mortality study. Br F Ind Med 1991;48:229-33.

34 Selikoff IJ, Seidman H, Hammond EC. Mortality effects of cigarette smoking among amosite asbestos factory workers. 7 Natl Cancer Inst 1980;65:507-13.

35 Selikoff IJ, Hammond EC. Multiple risk factors in environmental cancer. In: Fraumeni JFJr, ed. Persons at high risk of cancer: an approach to cancer etiology and control. New York: cancer: an approach to cancer etio

36 Hammond EC, Selikoff IJ, Seidman H. Asbestos exposure, cigarette smoking and death rates. Ann N Y Acad Sci 1979; 330:473-90.

37 Lee PN. Comparison of autopsy, clinical and death certificate the published data. APMIS 1994:102(suppl 45):42. 